\title{
EVALUASI KINERJA SISTEM RBC DI IPAL LAMBUNG MANGKURAT: PENGARUH VARIASI WAKTU TINGGAL TERHADAP EFISIENSI PENURUNAN KADAR BOD
}

\section{EVALUATION OF RBC SYSTEM PERFORMANCE IN LAMBUNG MANGKURAT WWTP: EFFECT OF DETENTION TIME TO EFFICIENCY BOD REMOVAL}

\author{
Lia Kurnia Putri ${ }^{1}$ \\ 1) Jurusan Teknik Sipil dan Lingkungan, Universitas Lambung Mangkurat, \\ Jl. Jend. Achmad Yani KM. 36, Banjarbaru, 70714 \\ ${ }^{1)}$ E-mail: Liakrnia@gmail.com
}

\begin{abstract}
Abstrak
Pengelolaan terhadap sanitasi khususnya air limbah domestik menjadi kebutuhan yang sangat crusial. IPAL Lambung Mangkurat menerapkan teknologi Rotating Biological Contactor (RBC) sebagai pengolahan air limbah. RBC merupakan salah satu pengolahan sekunder yang memanfaatkan mikroorganisme untuk menguraikan bahan organik yang terdapat di dalam air limbah. Penelitian ini bertujuan untuk melakukan evaluasi terhadap kinerja RBC di IPAL Lambung Mangkurat dan pengaturan variasi waktu tinggal untuk mengetahui pengaruhnya terhadap efisiensi pengolahan RBC dalam menurunkan kadar BOD. Evaluasi terhadap kinerja RBC tersebut dilakukan dengan mengukur kondisi sebelum dan sesudah perlakuan. Perlakuan variasi waktu tinggal dilakukan dengan cara mengatur pompa pengontrol pada bak RSPS dengan valve pada pipa inlet bak pengendap pertama. Nilai tipikal waktu tinggal diambil dari nilai yang paling kecil ( $0,7 \mathrm{jam})$, nilai tengah $(1,1 \mathrm{jam})$ dan nilai paling besar $(1,5 \mathrm{jam})$. Hasil dari penelitian ini, pada kondisi eksisting debit air limbah yang diolah di RBC berkisar 530,713 $\mathrm{m}^{3} / \mathrm{hari}-615,385 \mathrm{~m}^{3} / \mathrm{hari}$ dengan waktu tinggal antara 0,7 - 4 jam yang tergantung dari waktu pompa. Adanya perlakuan variasi waktu tinggal memberikan pengaruh terhadap efisiensi penurunan kadar BOD. Waktu tinggal yang menurunkan kadar BOD paling besar yaitu $1,5 \mathrm{jam}$.
\end{abstract}

Kata kunci: Air limbah, BOD, Evaluasi, RBC, Waktu tinggal.

\begin{abstract}
Currently, the management of sanitation especially domestic wastewater is very crucial. Lambung Mangkurat WWTP is applying the Rotating Biological Contactor (RBC) technology in the wastewater treatment. $R B C$ is a type of secondary treatment that uses microorganisms to decompose organic material in wastewater. The purpose of this study is to evaluate the performance of RBC in Lambung Mangkurat WWTP and how variation of detention time affects the efficiency of BOD removal in the RBC process. RBC performance evaluation was conducted by measuring the conditions before and after treatment. The analysis of detention time variation was done by combining the use of a pump in RSPS (Raw Sewage Pump Station) and a valve in the primary clarifier. The typical detention time was adjusted from the minimum value of 0.7 (hours), median 1.1 (hours) and maximum 1.5 (hours). The results of this study showed that the existing flow rate processed ranged from $530.713 \mathrm{~m}^{3} /$ day- $615.385 \mathrm{~m}^{3} /$ day with detention time between $0.7-4$ hours depending on the time of the pump. The variation of detention time affected the efficiency of BOD removal. The highest BOD removal was generated with the detention time of 1.5 (hours).
\end{abstract}

Keywords: BOD, Detention time, Evaluation, RBC, Wastewater. 


\section{PENDAHULUAN}

IPAL Lambung Mangkurat menggunakan sistem pengolahan biologi dengan Rotating Biological Contactor (RBC). RBC merupakan pengolahan sekunder yang terdiri atas disk melingkar yang diputar oleh poros dengan kecepatan tertentu. Polutan organik yang terkandung di dalam air limbah akan diuraikan oleh mikroba yang tumbuh di media $\mathrm{RBC}$, dengan sistem biakan melekat (attached culture) (Said, 2005). Parameter utama yang mempengaruhi proses pengolahan dengan RBC adalah Biochemical Oxygen Demand (BOD) (Azizah, 2015). Menurut Suryo (2009) RBC dapat menyisihkan BOD sebesar 90\%, sedangkan menurut Badan Pengkajian dan Penerapan Teknologi (BPPT) (2011) efisiensi pengolahan dengan RBC adalah 80-95\%. Kinerja sistem RBC dapat dilihat dari efisiensi RBC dalam mengurangi beban organik yang ada di dalam air limbah. Evaluasi kinerja sistem RBC dilakukan untuk mengetahui kinerja sistem RBC sudah berjalan optimal dan efektif atau belum. Apabila kinerja sistem RBC belum berjalan optimal dan efektif maka dapat diberikan perlakuan (Azizah, 2015). Perlakuan tersebut dapat berupa pengaturan debit dan waktu tinggal. Berdasarkan kriteria desain oleh Metcalf \& Eddy (2003) waktu tinggal di RBC berkisar antara 0,7-1,5 jam.

Pada penelitian Hartati (2014) dilakukan evaluasi kinerja sistem RBC di IPAL Pekapuran Raya dengan melakukan pengaturan debit dan variasi waktu tinggal sesuai kriteria desain oleh Metcalf \& Eddy (2003). Pada kondisi eksisting, debit air limbah yang masuk dan diolah di RBC berkisar 138,24 $\mathrm{m}^{3} /$ hari - $667,872 \mathrm{~m}^{3} /$ hari dengan waktu tinggal yang bervariasi yaitu berkisar 0,6 - 3 jam. Efisiensi penurunan kadar BOD rata-rata dengan sistem RBC dari inlet sampai outlet di IPAL ini sebelum dilakukan perlakuan sekitar $30,05 \%$. Setelah dilakukan pengaturan dan perlakuan terhadap RBC efisiensi penurunannya sekitar $90 \%$ dengan waktu tinggal 1,5 jam. Azizah (2015) juga melakukan evaluasi kinerja sistem RBC di IPAL HKSN/Hasan Basry dengan perlakuan yang sama yaitu mengatur debit dan variasi waktu tinggal sesuai kriteria desain oleh Metcalf \& Eddy (2003). Pada kondisi eksisting, debit air limbah yang masuk dan diolah di RBC berkisar 557 $\mathrm{m}^{3} /$ hari - $642 \mathrm{~m}^{3} /$ hari dengan waktu tinggal yang bervariasi yaitu berkisar 0,6 - 0,9 jam. Efisiensi penurunan kadar BOD rata-rata dengan sistem RBC dari inlet sampai outlet di IPAL ini sebelum dilakukan perlakuan sekitar $21,51 \%$ dan setelah dilakukan perlakuan terhadap RBC efisiensi penurunannya sekitar $80 \%$ dengan waktu tinggal 1,5 jam.

Berdasarkan uraian di atas penulis akan melakukan evaluasi kinerja sistem RBC di IPAL Lambung Mangkurat dan pengaturan variasi waktu tinggal sesuai kriteria desain yang telah ditentukan. Parameter yang digunakan pada penelitian ini adalah BOD. Penelitian ini diharapkan dapat mengetahui efisiensi pengolahan RBC dalam menurunkan kadar BOD secara optimal, efektif dan efisien.

\section{METODA}

\section{Rancangan Penelitian}

Evaluasi kinerja sistem RBC di IPAL Lambung Mangkurat dilakukan pada skala lapangan dan skala laboratorium. Penelitian skala lapangan dengan melakukan pengaturan debit dan variasi waktu tinggal pada pompa yang terdapat di bak RSPS dengan valve pada pipa inlet bak pengendap pertama. Valve diatur dengan cara menutup valve sebanyak $1 / 4,1 / 2$ atau $3 / 4$ bagian tergantung dengan pasokan air yang akan masuk. Pengukuran debit dilakukan terdiri atas 2 tahap yaitu pengukuran debit awal (penentuan jam dan hari puncak) serta debit (sebelum dan sesudah perlakuan). Pengukuran debit awal dilakukan pada bak RSPS selama 7 hari. Pengukuran dilakukan secara manual selama 24 jam untuk mengetahui debit yang masuk secara 
keseluruhan, sehingga dapat ditentukan jam dan hari puncak selama 7 hari tersebut. Jam dan hari puncak ini nantinya akan digunakan sebagai tolak ukur dalam pengukuran debit dan parameter kualitas air (sebelum dan sesudah perlakuan). Pengukuran debit (sebelum dan sesudah perlakuan) dilakukan di outlet RBC dengan menggunakan metode tampung. Pengukuran ini dilakukan pada jam dan hari puncak yang telah dilakukan pada kegiatan sebelumnya. Pengambilan sampel dilakukan 1 kali dalam sehari untuk seluruh variasi waktu tinggal pada inlet dan outlet RBC pada jam dan hari puncak. Pengujian BOD dilakukan di Laboratorium UPT Dinas Kesehatan. Hasil yang didapatkan kemudian dianalisis untuk mengevaluasi kinerja sistem RBC IPAL.

\section{Alat dan Bahan Penelitian}

Alat - alat yang digunakan dalam penelitian ini adalah :
a. Timba/ember $10 \mathrm{~L}$
b. Stopwatch
c. Meteran
d. Alat pengambil sampel yaitu gayung yang dilengkapi dengan tongkat
e. Botol sampel $1 \mathrm{~L}$
f. Gelas ukur
g. Kertas label
h. Box pendingin
i. Ice Replacement merk Thermafreezer
j. Gunting
k. Pengontrol pompa debit yang masuk ke sistem RBC
1. Valve
m. Sarung tangan
n. Masker

Bahan yang digunakan dalam penelitian ini adalah air limbah domestik daerah pelayanan IPAL Lambung Mangkurat, PD PAL Banjarmasin.

\section{HASIL DAN PEMBAHASAN}

\section{RBC IPAL Lambung Mangkurat}

IPAL Lambung Mangkurat memiliki kapasitas pengolahan $1000 \mathrm{~m}^{3} /$ hari yang terdiri atas 2 buah RBC dengan kapasitas masing-masing RBC sebesar $500 \mathrm{~m}^{3} /$ hari. RBC ini terletak pada bangunan yang berbeda. Pada unit pengolahan RBC bangunan pertama air limbah diolah melalui 4 tahap. RBC bangunan pertama memiliki panjang reaktor $15,7 \mathrm{~m}$ dan lebar reaktor sebesar 1,25 m. Pada RBC bangunan kedua terdiri dari 3 tahap. RBC bangunan kedua memiliki panjang reaktor sebesar $8 \mathrm{~m}$, lebar reaktor sebesar $2,7 \mathrm{~m}$ dan tinggi reaktor sebesar 1,5 m. Ukuran diameter disk RBC masing-masing sebesar 2,4 $\mathrm{m}$ dengan tebal media $1 \mathrm{~mm} /$ lembar sebanyak 60 lembar dalam 1 paket disk. Kecepatan putaran masing-masing RBC sebesar 3,75 rpm.

\section{Pengukuran Debit IPAL Lambung Mangkurat Penentuan Hari dan Jam Puncak}

Pengukuran ini bertujuan untuk mengetahui fluktuasi debit air limbah yang masuk setiap hari dan setiap jamnya sehingga dapat ditentukan hari dan jam puncaknya. Jam dan hari puncak digunakan sebagai acuan pada pengukuran debit dan waktu tinggal eksisting, pengaturan variasi debit dan waktu tinggal, serta pengukuran parameter BOD.

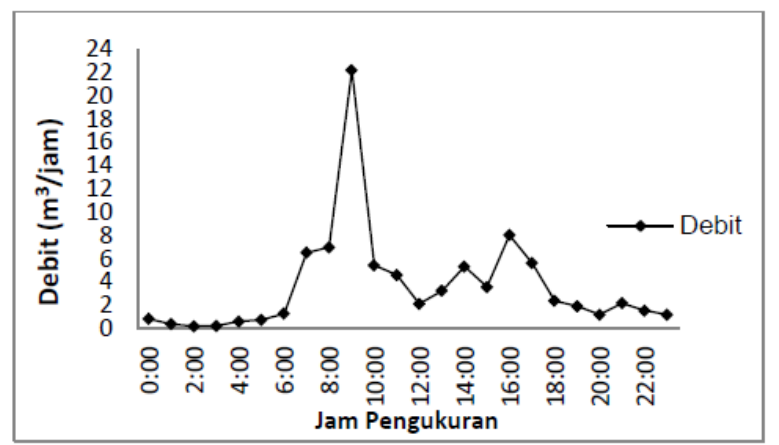

Gambar 1. Grafik Fluktuasi Debit Air Limbah Setiap Jam 
Debit puncak terjadi pada jam 09.00 WITA. Pada jam tersebut terdapat kiriman air limbah dari PS 4 yang dapat dilihat pada Gambar 1 . Hari puncak diambil berdasarkan perwakilan hari kerja, hari diantara hari kerja dan libur, serta hari libur. Perwakilan hari kerja diwakili oleh hari Rabu, hari diantara hari kerja dan libur diwakili oleh hari Jumat dan perwakilan hari libur diwakili oleh hari Minggu yang dapat dilihat pada Gambar 2.

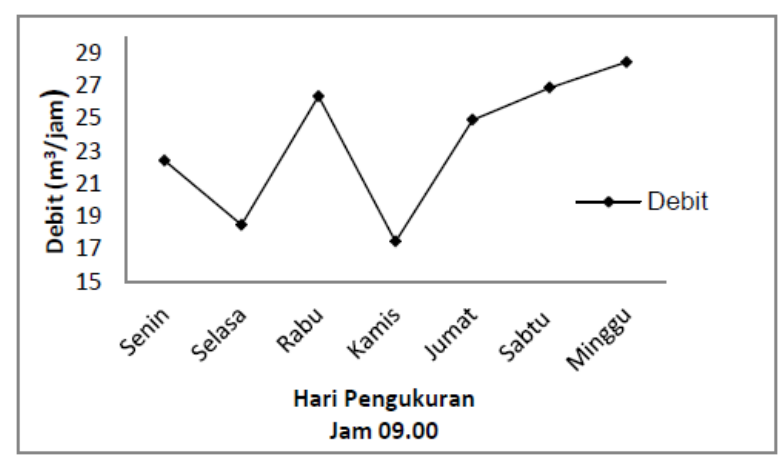

Gambar 2. Grafik Fluktuasi Debit Air Limbah Selama 7 hari

\section{Pengukuran Debit Eksisting RBC IPAL Lambung Mangkurat Berdasarkan Hari dan Jam Puncak}

Pengukuran debit eksisting dilakukan untuk mengetahui nilai debit yang masuk pada pengolahan unit RBC, sehingga didapatkan waktu tinggal. Besar nilai debit yang masuk tergantung dari operasional pompa yang dijalankan oleh operator dapat dilihat pada Tabel 1.

Tabel 1. Rekapitulasi Perhitungan Debit dan Waktu Tinggal Eksisting

\begin{tabular}{ccc}
\hline Hari ke- & Debit $\left(\mathrm{m}^{3} /\right.$ hari $)$ & td (jam) \\
\hline 1 & 530,713 & 4 \\
2 & 575,233 & 2.5 \\
3 & 615,385 & 0.7 \\
\hline
\end{tabular}

Nilai debit pada hari kesatu, kedua dan ketiga berbeda-beda, tergantung dari banyak tidaknya air di inlet. Air limbah yang ada di inlet berasal dari air limbah yang dibuang oleh masyarakat wilayah layanan IPAL Lambung Mangkurat, sedangkan untuk waktu tinggal eksisting, hari kesatu dan kedua didasarkan pada waktu pompa, namun pada hari ketiga waktu tinggal didasarkan pada perhitungan. Waktu tinggal tersebut sesuai dengan kriteria desain menurut Metcalf \& Eddy (2003) yaitu berkisar antara 0,7 - 1,5 jam. Hal ini disebabkan karena pada hari tersebut debit air limbah yang masuk di inlet banyak yang dapat dilihat pada Tabel 1 .

\section{Pengukuran Parameter BOD Eksisting RBC IPAL Lambung Mangkurat Berdasarkan Hari dan Jam Puncak}

Parameter BOD digunakan untuk menentukan tingkat pencemaran bahan organik pada air limbah. Pada hari kesatu sampai hari ketiga nilai BOD mengalami penurunan dari inlet sampai outlet RBC yang dapat dilihat pada Gambar 3. Penurunan ini disebabkan karena terjadinya proses biologis di pengolahan unit RBC, mikroorganisme aerob menguraikan senyawa organik dalam air limbah, sehingga jumlah oksigen yang terlarut di air menjadi meningkat.

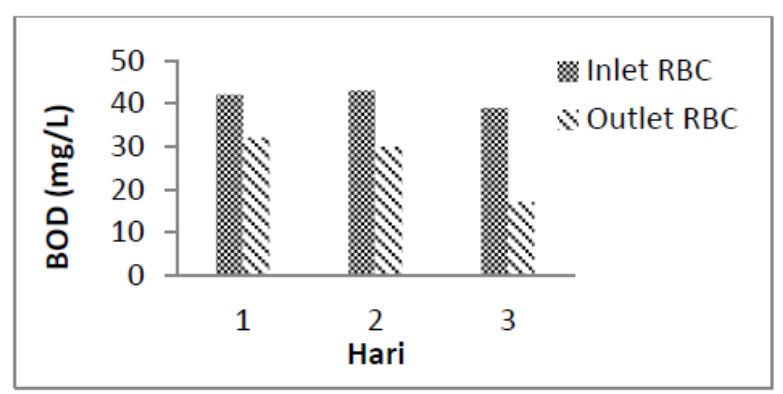

Gambar 3. Grafik Parameter BOD Eksisting

Nilai BOD pada inlet digunakan untuk menghitung beban organik yang diolah pada unit RBC. Berdasarkan hasil perhitungan, beban organik eksisting sebesar $18-20$ $\mathrm{gr} . \mathrm{BOD} / \mathrm{m}^{2}$.hari nilai tersebut belum memenuhi kriteria desain menurut Metcalf \& Eddy (2004) yaitu 12 - 15 gr.BOD $/ \mathrm{m}^{2}$.hari, sehingga dikatakan pengolahan tersebut belum bekerja secara optimal. Beban organik 
yang tinggi akan memberikan efisiensi yang rendah.

Efisiensi penurunan kadar BOD rata-rata dengan sistem RBC sebesar 36\%. Nilai efisiensi tersebut digunakan untuk mengetahui kinerja unit RBC di IPAL Lambung Mangkurat sebelum dilakukan perlakuan. Efisiensi penurunan kadar BOD yang kecil disebabkan karena kandungan nilai BOD pada air limbah yang masuk sudah sangat rendah. Rendahnya kandungan nilai BOD ini terjadi karena adanya pengenceran akibat infiltrasi air hujan dan air sungai di bak inlet dan sistem jaringan.

\section{Pengaturan Debit Berdasarkan Waktu Tinggal}

Pengaturan debit dan waktu tinggal dilakukan bertujuan untuk mendapatkan nilai debit yang diinginkan sesuai dengan waktu tinggal yang telah ditentukan sebelumnya. Waktu tinggal diambil tiga variasi nilai yaitu nilai yang paling kecil $(0,7$ jam), nilai tengah $(1,1$ jam $)$ dan nilai paling besar $(1,5$ jam $)$ berdasarkan Metcalf \& Eddy (2003). Setiap variasi waktu tinggal memiliki nilai debit yang berbedabeda dapat dilihat pada Tabel 2 .

Tabel 2. Rekapitulasi Perhitungan Debit, Waktu Tinggal dan Area Media Terendam pada Setiap Perlakuan

\begin{tabular}{cccc}
\hline $\begin{array}{c}\text { Hari } \\
\text { ke- }\end{array}$ & $\begin{array}{c}\text { Debit } \\
\left(\mathrm{m}^{3} / \text { hari }\right.\end{array}$ & $\begin{array}{c}\text { Waktu } \\
\text { tinggal } \\
(\text { Jam })\end{array}$ & $\begin{array}{c}\text { Area media } \\
\text { terendam }(\%)\end{array}$ \\
\hline \multirow{2}{*}{1} & 590,164 & 0,705 & 37 \\
& 366,723 & 1,109 & 36 \\
& 271,016 & 1,501 & 36 \\
2 & 590,971 & 0,712 & 38 \\
& 366,412 & 1,110 & 36 \\
3 & 273,764 & 1,503 & 37 \\
3 & 373,702 & 1,114 & 38 \\
& 267,990 & 1,500 & 36 \\
\hline
\end{tabular}

Waktu tinggal 0,7 jam memberikan nilai debit yang besar, namun sebaliknya pada waktu tinggal 1,5 jam memberikan nilai debit yang kecil (Tabel 2). Sehingga dapat dikatakan bahwa semakin kecil nilai debit maka waktu tinggal yang terjadi juga lebih lama. Debit aliran yang rendah menunjukkan semakin lama waktu tinggal air limbah di dalam reaktor RBC. Waktu tinggal yang lama memberikan kesempatan mikroorganisme untuk mendegradasi beban organik pada air limbah semakin besar (Suryo, 2009). Besar nilai debit pada setiap variasi merupakan nilai hasil perhitungan untuk mendapatkan waktu tinggal sesuai dengan variasi yang telah ditentukan.

Debit yang masuk pada reaktor menyebabkan tinggi air menjadi berubah-ubah pada setiap variasi waktu tinggal. Hal ini tentu memberikan pengaruh terhadap pembentukan biofilm oleh mikroorganisme. Menurut Sayekti (2012) semakin besar area media yang tercelup, maka pembentukan lapisan mikroorganisme pada permukaan media RBC menjadi optimal karena memberikan area kontak dengan air limbah yang lebih besar pula. Nilai debit yang besar memberikan area media terendam sekitar $38 \%$, dan nilai debit yang kecil memberikan area media terendam sekitar 36-37\% (Tabel 2). Nilai persentase area media terendam tersebut sesuai dengan kriteria desain menurut Metcalf \& Eddy (2004) yaitu 35-40 \%, sehingga pada setiap perlakuan variasi waktu tinggal terbentuknya biofilm oleh mikroorganisme pada media dikatakan sudah optimal.

Selain area media terendam, salah satu yang mempengaruhi pembentukan biofilm pada media RBC yaitu kecepatan putaran. Kecepatan putaran membantu dalam transfer oksigen dan nutrisi yang diperlukan untuk pertumbuhan mikroorganisme dalam biofilm (Laili, 2014). Kecepatan putaran di IPAL ini tidak memberikan pengaruh yang signifikan, karena pada sebelum dan sesudah perlakuan kecepatannya sama yaitu $\pm 3,75 \mathrm{rpm}$. Hal ini 
menunjukkan bahwa banyak/ tidaknya debit yang masuk pada inlet RBC tidak mempengaruhi kecepatan putaran $\mathrm{RBC}$ dan dikatakan kecepatan putaran ini masih berada pada kisaran 3 - 6 rpm (BPPT, 2011). Kecepatan putaran yang terlalu cepat memberikan proses pembentukan lapisan mikroorganisme pada permukaan media RBC menjadi kurang optimal, karena waktu kontak antara biofilm dengan air limbah maupun udara kurang. Namun, apabila kecepatan putaran terlalu lambat dapat menyebabkan mikroba tua yang berada pada permukaan media tidak dapat jatuh ke permukaan air (Sayekti, 2012).

\section{Pengukuran Parameter Kualitas Air RBC IPAL Lambung Mangkurat pada Setiap Perlakuan}

Pengukuran BOD pada penelitian ini digunakan untuk mengetahui efisiensi pengolahan di unit RBC. Waktu tinggal 1,5 jam memiliki efisiensi penurunan BOD paling besar dan paling kecil waktu tinggal 0,7 jam yang dapat dilihat pada Gambar 4.

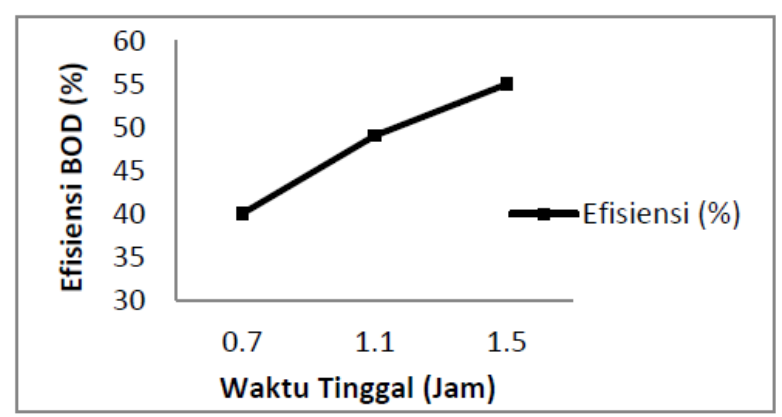

Gambar 4. Grafik Efisiensi BOD pada Setiap Perlakuan

Hal ini menunjukkan semakin lama waktu tinggal, efisiensi penurunan BOD juga semakin besar. Waktu kontak air limbah yang lama di dalam reaktor RBC membuat kemampuan penyisihan BOD oleh mikroorganisme semakin meningkat (Suryo, 2009). Lamanya waktu kontak antara air limbah dengan mikroorganisme dalam reaktor pengolahan secara biologi sangat berpengaruh terhadap efisiensi dan kinerja reaktor. Sesuai dengan penelitian Hartati (2014) dan Azizah (2015) dengan debit aliran yang rendah, maka waktu tinggal di RBC semakin lama, sehingga memberikan kesempatan pada mikroorganisme untuk mendegradasi beban organik dalam jumlah yang besar.

Beban organik (Bo) merupakan jumlah organik yang ada di dalam air limbah yang diolah pada unit RBC. Berdasarkan perhitungan dari ketiga variasi waktu tinggal, beban organik paling besar terjadi pada saat waktu tinggal paling singkat yaitu 0,7 jam. Pada waktu tinggal 0,7 jam nilai Bo sebesar 26,616 gr.BOD $/ \mathrm{m}^{2}$.hari; waktu tinggal 1,1 jam nilai Bo sebesar 14,721 gr.BOD/m ${ }^{2}$.hari dan waktu tinggal 1,5 jam nilai Bo sebesar 11,251 gr.BOD $/ \mathrm{m}^{2}$.hari. Semakin kecil beban organic, maka efisiensi penurunan kadar BOD semakin besar (Azizah, 2015).

Efisiensi penurunan kadar BOD yang kecil disebabkan karena kandungan nilai BOD pada air limbah yang masuk sudah sangat rendah. Sehingga perlakuan tiga variasi waktu tinggal yang dilakukan pada penelitian ini belum memenuhi kriteria desain karena menurut BPPT (2011) efisiensi pengolahan RBC mencapai 80-95\%. Dari penelitian Hartati (2014) perlakuan variasi waktu tinggal terhadap pengolahan RBC dapat menurunkan kadar BOD sekitar 90\% dan Azizah (2015) sekitar $80 \%$ sedangkan pada penelitian ini hanya mampu menurunkan sekitar 55\%. Adanya perbedaan ini disebabkan karena kondisi IPAL Lambung Mangkurat yang sedikit berbeda dengan IPAL dari dua penelitian sebelumnya baik dari sistem pengoperasian, wilayah layanan dan kapasitas pengolahannya, seperti yang telah dijelaskan sebelumnya akibat dari pengoperasian pompa yang dilakukan secara manual membuat air yang masuk ke pengolahan tidak berjalan secara kontinyu, sehingga dapat mempengaruhi efisiensi pengolahan. Sampel hasil pengukuran DO yang disimpan lebih dari 1 x 24 jam juga dapat mempengaruhi nilai hasil pengukuran BOD, nilai BOD pada 
inlet dan outlet $\mathrm{RBC}$ digunakan sebagai acuan untuk menghitung efisiensi penurunan kadar BOD.

\section{KESIMPULAN}

Kesimpulan yang dapat diambil dari hasil penelitian ini adalah :

1. Pada kondisi eksisting, debit air limbah yang masuk dan diolah di RBC berkisar $530,713 \mathrm{~m}^{3} /$ hari $-615,385 \mathrm{~m}^{3} /$ hari dengan waktu tinggal berkisar antara 0,7 - 4 jam tergantung dari waktu pompa. Beban organik yang besar menyebabkan efisiensi pengolahan hanya $36 \%$.

2. Waktu tinggal yang lama dapat meningkatkan efisiensi penurunan parameter BOD, namun waktu tinggalnya disesuaikan dengan kriteria desain.

\section{DAFTAR PUSTAKA}

Ananta, A.N dan Hendrasarie, N. (2014). Penyisihan Kandungan Organik Limbah Melalui Penentuan Konstanta Substrat Dengan Menggunakan Rotating Biological Contactor (RBC). Jurnal Ilmiah Teknik Lingkungan, Vol. 5 No. 2 (9-16). Program Studi Teknik Lingkungan Universitas Pembangunan Nasional Veteran, Jatim.

Azizah, A. (2015). Evaluasi Kinerja Sistem RBC (Rotating Biological Contactor) di IPAL HKSN/Hasan Basry PD PAL Kota Banjarmasin : Pengaruh Variasi Waktu Tinggal Terhadap Efisiensi Penurunan Kadar BOD. Skripsi Program Sarjana Teknik Lingkungan. Universitas Lambung Mangkurat, Banjarbaru.

Badan Pengkajian dan Penerapan Teknologi. (2011). Kelompok Teknologi
Pengelolaan Air Bersih dan Limbah Cair. Jakarta Pusat.

Hartati, E.S. (2014). Evaluasi Kinerja Sistem RBC (Rotating Biological Contactor) di IPAL HKSN/Hasan Basry PD PAL Kota Banjarmasin : Pengaruh Variasi Waktu Tinggal Terhadap Efisiensi Penurunan Kadar BOD. Skrips Program Sarjana Teknik Lingkungan. Universitas Lambung Mangkurat, Banjarbaru.

Laili, F.R., Liliya, D.S., Bambang, S. (2014). Efisiensi Rotating Biological Contactor Disc Datar dan BalingBaling dengan Variasi Kecepatan Putaran Pada Pengolahan Limbah Cair Tahu. Jurnal Sumberdaya Alam dan Lingkungan, (71-77). Universitas Brawijaya, Malang.

Metcalf dan Eddy. (2003). Waste Water Engineering Second Edition. New York: Mc Graw-Hill Company.

Peraturan Gubernur Kalimantan Selatan Nomor 36 Tahun 2008 Tentang Baku Mutu Limbah Cair Bagi Kegiatan Industri, Hotel, Restoran, Rumah Sakit, Domestik dan Pertambangan.

Said, N.I. (2005). Pengolahan Air Limbah Dengan Sistem Reaktor Biologis Putar (Rotating Biological Contactor) dan Parameter Desain. JAI, Vol. 1 No. 2 (178-188).

Sayekti, R.W., Haribowo, R., Vivit, Y., Prabowo A. (2012). Studi Efektifitas Penurunan Kadar BOD, COD dan $\mathrm{NH}_{3}$ pada Limbah Cair Rumah Sakit dengan Rotating Biological Contactor. Jurnal Pengairan, Vol. 2 No. 2. Jurusan Teknik Pengairan Fakultas Teknik Universitas Brawijaya, Malang. 
Suryo, P.Y. (2009). Aplikasi Rotar Biological Contactor untuk Menurunkan Polutan Limbah Cair Domestik Rumah Susun Wonorejo Surabaya. Seminar Nasional Implementasi Teknologi Informasi dalam Pengembangan Industri Pangan, Kimia dan Manufaktur. Teknik Industri \& LPPM UPN Veteran. Jawa Timur. 